\title{
The Conspiracy That Never Existed: How Hawai'i Evaded Annexation in 1868
}

\begin{abstract}
America responded to rumors of a crisis between Hawai' $i$ and France by sending a fully manned warship to Honolulu to safeguard the interests of Americans in the Islands. Arriving on February 9, 1867 , the U.S.S. Lackawanna was under orders to remain in Hawai' $\mathrm{i}$ permanently. Approximately one year later, George W. Lendeveg, ${ }^{1}$ captain's clerk aboard the ship, warned Kamehameha V, the monarch of Hawai' i, that "some few of the Americans, + English residents have went $[s i c]$ so far as to advise revolution to put these Islands under the American flag, . . "2 Lendeveg then passed stolen information to the Hawaiians and implicated his captain in the conspiracy to incite rebellion. That action placed him in an untenable position between two countries that needed each other more than they needed him. This paper will analyze America's attempt to undermine Hawaiian sovereignty during the Lackawanna affair, and reveal how George Lendeveg played an unwitting role in preserving the independence of Hawai'i.
\end{abstract}

David Zmijewski has previously written on Mark Twain for the Journal. He is the author of numerous articles, including an upcoming contribution to the Encyclopedia of American Conspiracy Theories. He is now completing a book that traces the Hawaiian influence on Mark Twain's Adventures of Huckleberry Finn. Dr. Zmijewski, who has a Ph.D. in American Studies from the University of Hawai 'i at Mānoa, is an associate professor of American studies at Baika Women's College in Osaka, Japan.

The Hawaiian Journal of History, vol. 37 (2003) 


\section{The Making of the Conspiracy}

An associate justice of the Hawaiian Supreme Court, George M. Robertson, may have precipitated the dispatch of the Lackawanna when his letter to James F. B. Marshall of Boston was brought to the attention of U.S. officials. Robertson wrote, "I have no doubt we shall see a French Man of War here in a few months. But I trust the United States and Britain will save us from going under the French flag." ${ }^{3}$ Less than seven months after Robertson's letter, the Lackawanna, under the command of William Reynolds, anchored offshore without the permission of the Hawaiian government. In his memoirs, Charles de Varigny, who then served as the minister of foreign affairs for Hawai' $i$, charged that Reynolds "had solicited and obtained orders from his superiors to remain with his ship in Hawaiian waters, and to carry out what he [Reynolds] described as a "mission of surveillance.'" 4 Reynolds was familiar with Island politics and had a rapport with Americans there because he had been stationed in Hawai' $i$ in the $185^{\circ}$ and early 1860 s. During that time, he had gained notoriety as an avid annexationist, and according to Gavan Daws, the skipper "was back, and he was still talking about annexation." 5

During the time of the Lackawanna's mission, ministerial-level negotiations were underway to strengthen economic cooperation between the United States and Hawai'i. This Reciprocity Treaty had been drafted by Charles Coffin Harris, the former minister of finance who represented the Kingdom of Hawai' $i$, and his American counterpart, General Edward Moody McCook, and was slated to be presented to their respective legislatures for ratification. Per orders of his sovereign, Harris, who was in Washington lobbying Congress on the treaty, lodged a formal protest against the Lackawanna and Captain Reynolds to Secretary of State William Henry Seward:

I am instructed to represent to you Mr. Secretary that since the arrival of the Lackawanna in Hawaiian waters, the conduct of her Commander has been most unfriendly to the government. He has sought to make himself a power and influence in the community; has promoted attacks against the government, and those administering it; and has endeavored to stir up dissension, and to excite in this country [America], and in Hawaii, an unfounded apprehension of the insecurity of the government of Hawaii. ${ }^{6}$ 
Reynolds was definitely meddling in Island affairs. But was he simply trying to derail the passage of the trade treaty, or was he actually fostering an atmosphere of political turmoil that would free him to respond militarily? Lendeveg cautioned that Reynolds was offering a solution while serving as the catalyst. Letters from Reynolds to Admiral Henry K. Thatcher show that the captain preferred possession to a treaty, and in his history of Hawai' $\mathrm{i}$, Ralph S. Kuykendall concludes that Reynolds "was not adverse to the use of force, if necessary, to plant the American flag firmly on these islands." 7

American investment in Hawai' $i$ was substantial, and where dollars were at risk, protection was promised. With whaling in decline, American investors turned to sugar in search of profit; however, a viable sugar industry depended on low-cost access to American markets. Although a number of other products - coffee, raw cotton, fruits, vegetables, furs, and hides, among them-would also pass tariff-free into American ports, the Reciprocity Treaty would guarantee the health of the plantations by removing or lowering tariffs on certain grades of exported sugar. ${ }^{8}$ Contemporary observers of the economic relations between the two countries like Mark Twain, the future author of the Adventures of Huckleberry Finn (1885), argued that Honolulu survived solely because of American capital. In the tenth of a series of twenty-five travel letters written for the Sacramento Daily Union, many of which he penned on a four-month visit to Hawai'i in 1866 , Twain sermonized:

The whaling trade of the North Seas-which is by no means insignificant-centers in Honolulu. Shorn of it this town would die-its business men would leave and its real estate would become valueless, at least as city property, though Honolulu might flourish afterwards as a fine sugar plantation, . . ${ }^{9}$

With the limits of continental expansion reached, the United States targeted more distant territories to bring within its sphere of influence, and as a significant repository of American investment Hawai'i was an ideal candidate. An anonymous correspondent for The Philadelphia Inquirer of July 16, 1867, raised the issue of Island indebtedness. The writer stated that the King "owes all that he is to the kind and thoughtful solicitude of the American mission ...”, then 
extended that obligation to all Hawaiians: "His people owe everything that has elevated them beyond, and far beyond all other kindred cases in the Pacific, in education, morals and in the pursuits of the business of life, to our missionaries." 10 This defense of the long-term American investment of religion, culture, and money was merely a springboard for a more compelling solution. The author concluded that Americans were entitled to much more:

The Islands, if they could now come into our hands could be fortified, and made secure for our shipping in the event of future wars. In case of a war with England, our people in Oregon, and California, and the Territories, would overrun and hold British Columbia, which would give us the whole coast. ${ }^{11}$

Living with recent memories of a devastating domestic war, Americans would have been receptive to propaganda linking the possession of Hawai' $i$ with national security; any buffer between an external conflict and the mainland would have been a tactician's or a politician's dream. America, however, was not free to move unilaterally; England and France arguably had a say in the future of Hawai'i. England, France, and the United States, were engaged in a veiled tripartite struggle over who would eventually control the kingdom. The opinion seemed to be that Hawai'i was too important to retain its independence. Captain C. P. T. Laplace of France had threatened to attack Hawai' $i$ in 1839 if his demands were not acceded to, and in 1843 Lord George Paulet of England actually annexed the Islands to the British Empire. To gain an upper hand in this three-way standoff, Americans required the support of the Hawaiians themselves, or, at the very least, appeals from expatriates warning that the nation was doomed without assistance.

Such a sense of urgency is to be found in the personal correspondences of the American missionaries. These men were keenly aware of the debate over reciprocity and annexation, and though their opinions varied, most agreed that the spiritual and economic investments in the Islands had to be protected. For these exporters of Christian democracy, a self-righteous attitude often prefaced their entreaties for more direct involvement.

Writing to an O'ahu missionary in December 1867 , Reverend Elias Bond referred to the present monarch as "a dissolute infidel king" 
who was responsible for "one of the vilest and in every sense wickedest crusades against morals and religion, ever existing, . . ."12 Outraged by this alleged dissipation, Bond reversed his political stance. Eight months earlier, Bond regarded the talk of annexation as "all moonshine." 13 But by December he confessed: "I have always dreaded the idea of annexation to the U.S. because I have felt sure that the people $\mathrm{w}^{\mathrm{d}}$ soon be trodden down into the grave. But I w $\mathrm{w}^{\mathrm{d}}$ now do anything in my power to bring about annexation...." Bond appealed for American intervention to save the people from what he regarded as the "darkest hour" in the Islands since the missionaries arrived in 1820. ${ }^{14}$ Hawai'i's moral dilemma as depicted in such letters was effective propaganda for those Americans who may have doubted that they were politically justified in making Hawai' $i$ part of their territory.

Luther Halsey Gulick, a missionary who published and edited a Hawaiian language newspaper Ka Nupepa Kuokoa, had two powerful vehicles for promulgating his ideas: his position in the Church and the press. Gulick welcomed the Lackawanna to Hawaiian waters. In a confidential letter to N. G. Clark, the Boston secretary of the American Board of Commissioners for Foreign Missions (ABCFM), Gulick accused members of the English church and the King's cabinet of working against American interests. ${ }^{15} \mathrm{His}$ appeal addressed the prejudice against Americans presumably held by the highest officials in government. Gulick asserted:

It is high time American Commerce \& interests here were better cared for. It is high time that the American name were [sic] sustained on these islands as efficiently as the English and French. The American here is still under a cloud. We feel that there are certain ulterior plans, favoring other nationalities than America, which require the presence of American National Vessels. If American interests are ignored, or but partially cared for here, the time may come when she may find herself embarrassed with a Nassau on her Pacific Shores. ${ }^{16}$

Despite what Gulick declared were official anti-American sentiments, he averred that "the great body of the Hawaiian Nation is most favorably affected toward America, whatever may be the spirit of the present administration, \& the U.S. Govt. would do wisely to foster this feeling to the utmost." 17 To ensure the friendship of the people, Gulick was convinced that America should act decisively. A friendly 
warship was essential for the safety of the nation at large. Gulick implored Clark to "use all the influence you think prudent to secure the presence of the Lackawanna in our waters, for many months to come." 18 This petition to keep the Lackawanna in Hawai'i does not officially clarify his support for annexation; however, Henry A. P. Carter, a businessman born in Hawai'i of American parents, confirms that Gulick favored a change of masters. Carter wrote,

The outlying districts on the other islands are ripe for it [annexation] now and Dr. Gulick's paper is keeping them up to the point. We make one point to justify annexation to the natives that as the King will not allow them their rights and those they have enjoyed heretofore, they have a right to look for another sovereignty. ${ }^{19}$

Reciprocity was a natural step in the process towards annexation, but there were those who wished to circumvent the treaty altogether. Americans coveted the Islands, and since they expected to incorporate the territory into the Union eventually, why not sooner rather than later? The Lackawanna provided the means to speed up possession. Even when a friendly nation sends an uninvited warship into the harbor of an ally's capital on a permanent assignment, it is grounds for concern. For Kamehameha V, the situation was compounded because the only way to maintain Hawaiian sovereignty was through the balance of power among America, England, and France. With more military might than all that possessed by Hawai' $i$ anchored off the capital, Kamehameha was disempowered. And until the Lackawanna sailed or the balance of power restored by the arrival of a vessel from Britain or France, revolution was a real threat. The missionaries and the American-slanted English language press categorized the majority of native Hawaiians as pro-American, and claimed that these innocents needed protection from their unscrupulous monarch. Yet, Gulick's avowal that native Hawaiians sided with Americans was spurious, if not outright deception. The dowager Queen Emma was reported as saying in a conversation at the time, "that with few exceptions, all the natives were opposed to annexation." ${ }^{20}$ Although not publicly espoused as a preemptive strategy, annexation seems to have long been a topic of official confidentiality. On a stopover at Hawai' $i$ in 1866, Anson Burlingame, the U.S. minister en route to his 
post in China, was noncommittal about the need for a more active American role. In a letter to Secretary of State Seward, Burlingame dismissed the efficacy of British and French schemes:

At the Hawaiian Islands I heard much of foreign intrigues but after a careful examination of the evidence, I am constrained to say that, in my judgement, there is no danger to be apprehended from these; for the reason that our people are so alive to them, and because the Americans, and the natives who agree with them, constitute nearly the whole population. The King is said to be against us, and this may be true in so far as he naturally sympathizes with his confreres; but he can do nothing practically to harm us, and those who are to succeed him are quite in our interests. The business of the Islands is conducted by citizens of the United States - they are the principal land owners, and thirty years of missionary efforts exclusively American have impressed the native population with American ideals.21

This official reference to America's political inviolability was not Burlingame's only opinion, though. Mark Twain, who had been befriended by the minister while in Hawai' $i$, revealed in an 1873 letter to Whitelaw Reid, editor of the New York Tribune, that the now deceased Burlingame had coveted Hawai' $i$. Twain wrote that "Mr. Burlingame told me privately that if he were minister there he would have the American flag flying on the roof of the king's palace in less than two weeks. And he was in earnest, too. He hungered for those rich islands." 22 Private preferences gained official currency, and when circulated those ideas possessed the power to direct government policy. Confidential correspondences between General McCook and Secretary of State Seward exchanged before and during the height of the trade negotiations and the Lackawanna crisis substantiate this theory. After assuming his position as United States Minister in Hawai' $i$, General McCook stated that once the present king died, America would have the chance to extend its democracy. McCook wrote:

... when this dynasty ends, as end it will probably within the next year, I am sure that if the American Government indicates the slightest desire to test in these islands the last Napoleonic conception in the way of territorial extension you will find the people here with great unanim- 
ity 'demanding by votes, freely expressed, annexation to' the United States. ${ }^{23}$

McCook's assurances of the support of the people may have prompted Seward to make his own views on the future of Hawai'i perfectly clear:

It is proper that you should know, for your own information, that a lawful and peaceful annexation of the islands to the United States, with the consent of the people of the Sandwich Islands, is deemed desirable by this Government; and that if the policy of annexation should really conflict with the policy of reciprocity, annexation is in every case to be preferred. 24

Henry A. Peirce, successor to McCook as minister to Honolulu, verified that opinions favoring possession were widespread. After canvassing senators who would vote on the ratification of the Reciprocity Treaty, Peirce wrote to Edward P. Bond:

It is only in view of annexation that the Treaty has a ghost of a chance. Annexation-annexation seems to be the cry and object of all. If we can prevail with Senators to believe that the treaty will increase the chances of success of that great object, it will be ratified; and on no other ground. ...25 (italics in text)

Varigny, who was formerly on friendly terms with Reynolds, objected to the captain's "active participation in the maneuverings of the annexation party," and requested "clarification from Washington" on the U.S. government's official policy toward Hawai'i. ${ }^{26}$ Varigny contended that what he "learned was not very satisfactory. The administration hesitated to disavow unequivocally the compromising actions of its representative." 27 While not incriminating itself in any collusion, America's response, as remembered by Varigny, did not disabuse the Hawaiian government of the takeover danger.

Awareness of the strained relations between the two nations was public knowledge, and the mainland press exploited the diplomatic tension to proffer another option to reciprocity or annexation. The August 20, 1867, New York Daily Tribune suggested that if the trade 
negotiations faltered the capitalist's panacea should be given a chance:

... it does no violence to reason to suppose that another step might be taken whereby the same objects would be more effectually accomplished, and that the subject of the sale of the Islands had been broached in official circles. With the precedent furnished in the purchase of Alaska, there can hardly be a doubt that our Government would entertain favorably a proposition for the purchase of these islands. ... .

If they should come under our jurisdiction by purchase, a new and prosperous State would soon be added to the Union. ${ }^{28}$

A full year before the House voted in favor of the appropriation for the purchase of Alaska, which took place on July 14, 1868, McCook suggested to Seward that the Islands might be obtained for a price. Meiric Dutton chronicled that "General McCook wrote a private note to Secretary Seward, 'I think their sovereignty [i.e. of the Hawaiian Islands] could be purchased from the present King. . . . Will you permit me to suggest that you sound Mr. Harris on the subject?" 29

Even if outright purchase of the Islands was improbable, there were alternatives that would allow Americans to make further economic inroads while simultaneously increasing Hawai'i's indebtedness to, and dependence on, the United States. The Evening Bulletin, a San Francisco daily, reported that local capitalists were "about to negotiate for the purchase of the Sandwich Islands-that is, such tracts of land as are held in the name of the Hawaiian Government." 30 Notwithstanding the sensationalism of the article just quoted, the Hawaiians were neither selling their country nor compromising their way of life. But large subscription landholdings in the hands of foreign nationals compounded the potential to destabilize the Hawaiian economy should redemption in cash ever be demanded.

The Reciprocity Treaty was supported by the sugar planters in Hawai' $i$ because it would aid the industry by reducing or eliminating the tariffs on their exports to the United States. The mooring of the Lackawanna in Honolulu was a point of contention between the two governments and an obstacle to the passage of the treaty in the Hawai- 
ian legislature. Perhaps, it was to ease these tensions during the legislative debate that the Lackawanna departed for Midway Island. On August 28, 1867, Captain Reynolds took possession of Midway for the United States in an act that represented the first off-shore territorial annexation by America. ${ }^{31}$ The success of this extension of American influence must have inspired Captain Reynolds, who returned to Honolulu just a few days after the ratification of the treaty by the Island legislature.

Reynolds had begun America's extra-continental land-grabbing phase. This period of hegemonic expansion depended not only on the jingoistic belief in the integrity of the national democratic ideals, but also on the premise that the soon-to-be-annexed residents desired nothing other than becoming members of the American community. Press coverage touting the trade treaty, annexation, and outright purchase of Hawai' $i$ confirms that the popular trend in much of America was toward possession, regardless of what was best for the Islanders. And the permanent stationing of the Lackawanna in Hawai' $i$ contributed to the scenario that America might even have been positioning itself for an armed takeover of the kingdom.

\section{The Conspiracy Exposed}

Two letters from an officer stationed on the Lackawanna divulge that a conspiracy was developing. In the first of these, George Lendeveg explained to Kamehameha V that even though the subsequent disclosures could endanger his life, he felt obliged to inform his majesty that Reynolds was fomenting rebellion with the approval of his superiors. Lendeveg wrote:

The United States government I am certain approves of all Captain Reynolds is now doing and in time if all is allowed to remain as at present will go well. I will keep your Majesty fully informed, as all the diplomatic intrigue is carried on through Captn Reynolds, he being the only person the American residents trust and place confidence in. ${ }^{32}$

Without tendering absolute proof, Lendeveg named names. He incriminated, among others, a prominent missionary and adviser to Kamehameha V's predecessors (Gerrit P. Judd), the editor of The 
Pacific Commercial Advertiser (Henry M. Whitney), a businessman (William L. Green), and a minister to the king (Charles Coffin Harris). In his petition to secure a royal audience, Lendeveg included a melodramatic vow of loyalty to the monarch whom he adopted as his own: "I have entered on this with the determination of protecting this Kingdom against all persons both foreign and domestic and risk my life in so doing." 33 Since Lendeveg claimed some of the king's advisers might be involved, he wanted to present his evidence to the king in person. Lendeveg explained, "I want to show your Majesty the original documents or rather the letter books themselves, to yourself in person and not your Ministers because I do not fully trust them." 34

Lendeveg had already spent the better part of a year in Honolulu aboard the Lackawanna, and as captain's clerk he would have had access to official reports as well as the captain's private writings. These authentic documents should have been accepted as incontrovertible proof of Reynolds's involvement in a plot against the monarchy, but Lendeveg damaged his credibility by offering to ferret out the conspirators for profit. Enamored of a local girl, he solicited money and a position in exchange for the information. Lendeveg prefaced his tale of intrigue and rebellion with a pathetic personal message before arriving at the following solution: “. . . after thinking over matters I knew I had secrets in my possession that might set me in your Majesty's favor and at the same time give me a chance to win the loved one." 35

Primarily because of Lendeveg's privy commission aboard an uninvited warship did his accusations cause a commotion in the Hawaiian government. Still, it is surprising that the king sanctioned a cabinetlevel meeting to hear the facts. In his two letters, Lendeveg expressed opinions on many issues of national significance, including the unmarried king's choice of a successor. Was Lendeveg an astute observer of the problems facing Hawai' $i$ and someone to be trusted? Or was he a charlatan? A correspondent for the Alta California reported after the fact that "a softer, more addle-pated little simpleton [than Lendeveg] could scarcely be found." 36

Whatever Lendeveg may have been, the Lackawanna remained in Honolulu harbor and the Hawaiian government wanted it gone. Even though he diplomatically reaffirmed Hawai'i's official policy of 
cooperation with America, C. C. Harris made this demand explicitly clear in his March 3, 1868, letter to Secretary Seward:

There is not the smallest inclination that either of the great maritime powers [England and France], has the remotest intention, or even dreams of interfering with the Independence of the Kingdom, or indeed of interfering in any manner with the affairs thereof. There is therefore no reason arising from danger to American interests, either from within or without, that would call for an armed vessel—by many regarded as one of observation, being specially detailed by orders from Washington, to remain there, permanently to protect them.

Her presence there under such circumstances is represented by many ill-disposed persons as a menace and is perhaps felt to be so by many more, and has already had the effect to induce other foreign governments to place corresponding forces by her side. ${ }^{37}$

Due to concern over the threat to national sovereignty, the Hawaiian government granted Lendeveg an interview with Attorney General Stephen H. Phillips. In the follow-up letter to this meeting, the ever-suspicious Lendeveg insinuated that the attorney general might be withholding information, "I informed him [Phillips] as you are already aware (if he told all) that the American vessel of war was here for the ostensible reason of getting Your Majesty entangled by some means and then the American citizens on shore would rise, and aid the United States in taking possession." 38 That specific threat was ascribed a name, for Lendeveg reported that he had overheard Gerrit. P. Judd tell Reynolds that "the people were ripe for revolt, and would rise whenever the United States would stand by them." 39

This conspiratorial network became yet more complex when Lendeveg added another dimension to the intrigue; he argued that racism was rearing its ugly head and accused a businessman, presumably W. L. Green, of having said "the native rule had had sway long enough-the whites must rule. . ." 40 Lendeveg might very well have touched a sensitive chord here, for Kamehameha $\mathrm{V}$ and his predecessor, Alexander Liholiho, had experienced this racism firsthand during a diplomatic mission to the United States. ${ }^{41}$ Lendeveg seems to have been totally caught up in his own game as self-appointed hero and spy. He reported every detail that came his way, grasping for the 
clincher that would win his case. He claimed to have eavesdropped on people talking sedition. But what exactly had he heard? Political discussions may have been regarded as conspiratorial in some societies, but in America freedom of speech was a constitutional right. Those who Lendeveg overheard may have been pro-annexationists drawn in by the swashbuckling idealism of a powerful captain, but the conspiracy which Lendeveg warned about may have existed only in his impassioned imagination. Still, the accusations were serious and had to be investigated by the Hawaiian government.

\section{No Conspiracy; No Crime}

A chauvinistic reporter for the Alta California accused the Hawaiian government of embroiling Lendeveg in the conspiracy surrounding Reynolds. Penning his diatribe under the pseudonym J. Ebenezer Snickers, he wrote that after the matter was brought to the attention of the confidants of the king, there "forthwith arose a correspondence between the agents of the Hawaiian Government on the one side, and Lenderbeg $[\mathrm{sic}]$ on the other-the letters of the first breathing sweet promises of courtly influence to heal his broken heart, of vast sums of money $(\$ 1,500)$ to ease his conscience, and an office under the Government to render him respectable after his treachery; ..." 42 Snickers's prejudicial attitude negates all objectivity in his interpretation of the affair, for he contended that America was totally innocent. Snickers considered the affront so serious that he demanded satisfaction. Resurrecting historic abuses of power by England and France, he challenged America to save the nation's honor:

The more important aspect of the affair is, simply, that Kamehameha V. and his Ministers have, through their paid agents, boarded an American man-of-war, broken open a private despatch repository, and removed therefrom public documents that belonged to the United States.

Will our venerable Uncle pocket this insult, with the many others from the same quarter? We shall see. For a less insult than this the English flag once waved over Honolulu three months, and for a still less, a war with France was only averted by abject humiliation and the payment of a large sum of money. 43 
Despite opinions like this, the nation seemed uncertain of what response to make. The counterbalancing presence of a British warship may have deterred America from flexing its military muscle. ${ }^{44}$

Perhaps Lendeveg was overzealous in his appeals to the King, but it is clear from evidence presented earlier that officials at the highest levels of government desired to add Hawai'i to American territory. Lendeveg sounded the alarm over the conspiracy and subsequently moved to the very center of the crisis.

What could the Hawaiians do about Lendeveg? Act on the information and confront the United States? Ignore the entire affair? Or turn Lendeveg over to the Americans? After Lendeveg's audience with the attorney general, Varigny forwarded the two seditious letters to the secretary of state, and assured the U.S. that the Hawaiian government had contemptuously rejected Lendeveg's accusations. Varigny must have been aware that the disclosure could carry charges of treason-a capital offense. Lendeveg's good intentions may have been erringly motivated by personal distractions and the concomitant need for money, but he does seem to have been trying to aid the monarch during a diplomatic deadlock. Yet the Hawaiian government skillfully played the Lendeveg card forcing America's hand.

Hawaiian independence was threatened by an agent of the American military; Captain Reynolds disseminated information that could, if acted upon, subvert the sovereignty of the country. America wanted possession, and if Reynolds precipitated an event, the tedious years of reciprocity and economic cooperation might be skipped. As long as the Lackawanna stayed in Honolulu, Reynolds was free to sow dissension. The Hawaiian government needed something to trade, something to convince the Americans that they were serious about safeguarding the interests of the United States. It was fortuitous that Lendeveg surfaced on the scene with his conspiracy theory: Here was the perfect victim. No one, except perhaps the forlorn lover, would mourn his fate; and no one would rally to his defense. He was a traitor to America and a suspect in Hawai' $i$. For Hawai' $i$, there was no downside to the surrender of Lendeveg to the Americans, if diplomatic protocol was followed.

The charge that the American navy had a traitor in its ranks had to be official; otherwise, the Hawaiian government might be implicated in the subterfuge. Varigny's declaration to Seward opened thus: 
I am commanded by the King, my Sovereign, to transmit to Your Excellency the enclosed original documents [Lendeveg's letters]. Their origin and nature will be my excuse for resorting to this direct but unusual mode of transmission. The writer of the enclosed letters serves on the U. S. Ship of War 'Lackawanna'; the disclosures he pretends to make refer to a subject that has of late created some excitement in our quiet community. ${ }^{45}$

Varigny then justified the Crown's reasons for granting Lendeveg an interview with the attorney general.

That interview took place on the intimation that a certain witness, then unknown, would furnish valuable information of a conspiracy undertaken upon Hawaiian soil against the Hawaiian Government, involving even the personal safety of the King.

The witness proved to be the private Secretary of Captain Wm Reynolds, and his offers to communicate the papers and documents entrusted to his care or to which he had access were immediately rejected with the contempt they deserved. ${ }^{46}$

Varigny assured Seward of his sovereign's friendship: a tactic that should have rendered further artifice by the captain or crew of the Lackawanna diplomatically untenable. The minister of foreign affairs wrote that, ". . . the confidence of the King and of His Government in the honor and wisdom, as well as in the friendly dispositions of the Government of the United States, remains unimpaired, and cannot be affected by such communications as those I now transmit." 47 Varigny did not threaten, challenge, or recriminate. He averred that Hawai'i remained America's staunch ally and intimated that such honesty could only make the relationship stronger.

Even though the Lackawanna lingered on in Hawaiian waters, Reynolds could not assist in the execution of a rebellion, for the government of Hawai' $i$ had tested loyal to the United States. When Reynolds sailed on May 6, 1868, he carried Midway Island in his pocket and Lendeveg under arrest. But Hawai'i evaded his clutches and maintained its independence. The Islanders should have been thankful to the captain's clerk. His charges of a conspiracy permitted the response that may have preserved the sovereignty of Hawai' $i$. What was to become of Lendeveg? What was America to do with a traitor 
who compromised his captain and exposed a state-sanctioned conspiracy that never officially existed?

Once the Lackawanna returned to San Francisco, Lendeveg was court martialed on three charges approved by Admiral H. K. Thatcher: First, "Scandalous conduct tending to the destruction of good morals"; second, "Conduct unbecoming an officer and a gentleman"; third, "Conduct prejudicial to good order and naval discipline." 48 Each charge was subsequently divided into three or four specifications, and when asked how he pleaded to these serious offenses, Lendeveg neither acknowledged nor denied involvement, he answered, "I prefer to remain silent." 49

The Navy's sole witness was Captain Reynolds, and though Lendeveg contradicted points of Reynolds's testimony during the court martial, he seemed to base his hopes for acquittal on a written apology to the court, dated June 9, 1868. In that appeal, Lendeveg challenged the second specification. He argued that it had not been proven that he had turned over documents written by the captain to the king. He then explained how he had been lured into the plot by William P. Ragsdale, a lawyer and interpreter for the Hawaiian legislature. According to Lendeveg, Ragsdale

... invited me to his house under the guise of friendship and after exciting me with liquor until I can remember scarcely anything I told him, with fiendish cunning played upon the one subject that was nearest to my heart and upon which I had become a monomaniac, showing me on the one side a picture of poverty, debt and despair and on the other wealth, fame and happiness with her I loved better than all else upon earth and I, forgetting for the moment all other considerations told him I hardly know what and may have written any thing for I cannot tell what I would not have said or written then. ${ }^{50}$

Blaming intoxication and youthful inexperience for his predicament, Lendeveg asked for mercy. Regardless of the veracity of this postcourt martial confession and his deep regret, military tribunals are seldom lenient. Lendeveg was found guilty on all charges except the second specification in each count, which claimed that Lendeveg presented a copy of an official letter by Reynolds to King Kamehameha. ${ }^{51}$ Forfeiture of all pay due and a prison sentence of ten years at hard labor were the punishments meted out. Shortly after the ruling was 
handed down, Admiral Thatcher reduced the time at hard labor from ten years to five. ${ }^{52}$ Lendeveg must have felt relieved at the reduction in the sentence, but he almost certainly felt overjoyed when the attorney general's office rescinded the sentence entirely. ${ }^{53}$ The offenses for which Lendeveg was tried and convicted under military law warranted prison time or worse, yet the records show that the sentence was repealed and the prisoner freed. Perhaps Admiral Thatcher or the attorney general reasoned that criminal prosecution in this case would lead to accusations that America and Reynolds were in fact attempting to destabilize the Island nation and hasten annexation. By exonerating Lendeveg, the government revised history and disavowed that there had ever been a conspiracy. And without a conspiracy, no crime had been committed. The facts as presented here, however, prove that there had been both.

\section{Conclusion}

Hawaiian independence was imperiled in the late 1860 shen the U.S. dispatched the Lackawanna to protect the property of Americans. At that time the trade Reciprocity Treaty was being hailed as a route to better relations, yet in light of Captain Reynolds's annexationist background and Secretary Seward's land-grabbing proclivity, little doubt remains over America's motives-Hawai'i was a definite target for takeover either by ballot or force. The efforts to secure the country in 1868 failed, but the groundwork for the acquisition of Hawai'i had been laid: the Islands were just too important to remain independent. Even though Lendeveg's pilfered information may have proven unreliable, he represented a valuable commodity which the Hawaiians traded to preserve the status quo. Hawai'i proved its allegiance to the United States and defused the annexationist time bomb by exposing a traitor whose accusations were detrimental to both countries.

\section{Notes}

${ }^{1}$ George W. Lendeveg's name was repeatedly misspelled in the press: Lenderbeg and Linnebeck were two different versions.

${ }^{2}$ Geo. W. Lendeveg, Honolulu, to [King Kamehameha V, Honolulu], Feb. 12, 1868, Hawaiian Legation microfilm Feb. 1, 1847, to Dec. 26, $188_{5}$, Hamilton Library, U of Hawai'i at Mānoa. 
${ }^{3}$ George M. Robertson, Honolulu, to [J. F. B. Marshall, Boston], Jul. 10, 1866, in Ralph S. Kuykendall, The Hawaiian Kingdom, Vol. II, I854-I874 Twenty Critical Years (Honolulu: U of Hawai'i P, 1953) 213 n.

${ }^{4}$ Charles de Varigny, Fourteen Years in the Sandwich Islands I 855-I868, trans. by Alfons L. Korn (Honolulu: U of Hawai'i P and HHS, 1981) 206.

${ }^{5}$ Gavan Daws, Shoal of Time (Honolulu: U of Hawai'i P, 1968) 187.

${ }^{6}$ Charles Coffin Harris, Washington, to [William Henry Seward, Washington], Mar. 3, 1868, Hawaiian Legation microfilm Feb. 1, 1847, to Dec. 26, 1885, Hamilton Library, U of Hawai'i at Mānoa.

${ }^{7}$ Kuykendall, The Hawaiian Kingdom Vol. II, 214.

8 "Sandwich Islands Treaty," PCA, Oct. 17, 1867: 4 .

${ }^{9}$ Mark Twain, "Tenth Letter to the Sacramento Daily Union," Apr. 1866, rpt. in Walter Francis Frear, Mark Twain and Hawaii (Chicago: Lakeside Press, 1947) 308 .

10 “The Sandwich Islands," Philadelphia Inquirer, Jul. 16, 1867: 1.

11 Ibid.

12 Elias Bond, Kohala, to [Reverend Castle, Honolulu], Dec. 9, 1867, Castle Family Papers, Letters Received 1866-1867, HMCS, Honolulu, Hawai'i.

13 Elias Bond, Kohala, to [Reverend Castle, Honolulu], Apr. 22, 1867, Castle Family Papers, Letters Received 1866-1867, HMCS, Honolulu, Hawai'i.

14 Bond to Castle, Dec. 9, 1867 .

15 For more details about the trouble between the American missionaries and the English Church, see David Zmijewski, "Mark Twain and Hawaiian Politics: The Attack on Harris and Staley," Mark Twain Journal, Vol. 31, no. 2 (Fall 1993) $11-27$.

${ }^{16}$ Luther Halsey Gulick, Honolulu, to [Rev. N. G. Clark, Boston], Apr. 3o, 1867 , ABCFM-Hawai'i Papers, 1820-19oo, HMCS, Honolulu, Hawai'i. Originals in the Houghton Library, Harvard. Nassau is the capital of the Bahamas, an independent island nation today. Gulick was obviously cautioning against having a foreign entity, and therefore a potential military threat, so close to America's West Coast.

17 Ibid.

18 Ibid.

19 Henry A. P. Carter, to [Edward P. Bond], May 16, 1867, in Kuykendall, The Hawaiian Kingdom Vol. II, 221.

${ }^{20} \mathrm{~J}$. H. Wodehouse, to [British Foreign Office], Dec. 26, 1867, in Kuykendall, The Hawaiian Kingdom, Vol. II, 221.

21 Anson Burlingame, Shanghai, to [William Henry Seward, Washington], Sept. 19, 1866, Despatches from U.S. Ministers to China Jan. 6-Dec. 1866, roll 24, despatch number 1 19, microfilm, Hamilton Library, U of Hawai'i at Mānoa.

22 Mark Twain, Mark Twain's Letters Vol. 5 1872-1873, Lin Salamo and Harriet Elinor Smith, eds. (Berkeley: U of California P, 1997), 264.

${ }^{23}$ Edward McCook, Honolulu, to [William Henry Seward, Washington], Sept. 3, 1866, "A Study Series on the Question of Hawai 'i," Blount Investigation Files 
No. 6. Mr. McCook to Mr. Seward, Online. http://www.hookele.com/hawaii/ law-index.html: 8.

${ }^{24}$ William H. Seward, Washington, to [General Edward McCook], Sept. 12, 1867, in Edward Osborne Hooley, The U.S. and Hawaii I 85I-1876: A Study in Diplomatic Relation. (Ph.D. diss., U California at Berkeley, Dec. 1928) 255 .

${ }_{25}^{5}$ Henry A. Peirce, to [Edward P. Bond], Dec. 14, 1867, in John Patterson, "The United States and Hawaiian Reciprocity, 1867-1870," Pacific Historical Review vol. 7 (1938) 22.

${ }^{26}$ Varigny, Fourteen Years in the Sandwich Islands 1855-I 868: 206.

27 Ibid.

28 "The Transfer of the Sandwich Islands," New York Daily Tribune, Aug. 20, 1867: 5 .

${ }^{29}$ Meiric K. Dutton, "A Note on the Reciprocity Treaty of 1867 " (Honolulu: Loomis House Press, Hale Pai O Lumiki, MCMLII) no p.

30 "Letter from Honolulu," Evening Bulletin, June 29, 1868: 2.

31 "Chronicle of Events at Midway," Midway Atoll National Wildlife Refuge, Online. http://www.rl.fws.gov/midway/past/chronol.html.

32 Lendeveg to Kamehameha V, Feb. 12, 1868.

33 Ibid.

${ }^{34}$ Ibid.

35 Ibid.

${ }^{36}$ J. Ebenezer Snickers, "Voyage to Hawaii," Alta Califormia, May 25, 1868: 1.

${ }^{37}$ Harris to Seward, Mar. 3, 1868.

38 George W. Lendeveg, Honolulu, to [King Kamehameha V, Honolulu], copy dated Apr. 21, 1868, Hawaiian Legation microfilm Feb. 1, 1847, to Dec. 26, ${ }_{188}$, Hamilton Library, U of Hawai'i at Mānoa, Certified copy by Navy Department.

${ }^{39}$ Ibid.

40 Ibid.

${ }^{41}$ Frederick Anderson, Michael B. Frank, and Kenneth M. Sanderson, eds., Mark Twain's Notebooks $\mathcal{F}^{2}$ Journals, Vol. I (1855-1873), (Berkeley: U of California P, 1975), 15 o. One of these humiliating events occurred when the Princes were ordered out of a railroad car headed for Baltimore. The other took place on a Hudson River boat with the Princes being denied entrance to the dining salon. Both incidents happened during a diplomatic mission to the United States in 1850, and partially because of these insults the future Kings were perceived as favoring the British over Americans.

42 Snickers, "Voyage to Hawaii."

43 Ibid.

${ }^{44}$ See Harris to Seward, note 37 .

45 Charles de Varigny, Honolulu, to [William Henry Seward, Washington], Feb. 26, 1868 , Hawaiian Legation microfilm Feb. 1, 1847, to Dec. 26, 1885 , Hamilton Library, U of Hawai' $i$ at Mānoa.

46 Ibid. 


\section{THE HAWAIIAN JOURNAL OF HISTORY}

47 Ibid.

48 “Court Martial Records," No. 4816 to 4838 , Vol. 199, 1868. National Archives, Washington D.C., microfilm.

49 Ibid.

50 George W. Lendeveg, "Gentlemen of the Court," "Court Martial Records," No. 4816 to 4838 , Vol. $199,1868$.

50 Perhaps it was the wording in the charge that permitted Lendeveg to deny categorically this accusation. He did not have an audience with the king, rather the attorney general.

50 “Court Martial Records," No. 4816 to 4838 , vol. 199, 1868. Admiral Thatcher reduced the term of imprisonment from ten years to five years in an order signed and dated June $13,1868$.

${ }^{50}$ Rebecca A. Livingston, Washington, to [David Zmijewski, Osaka, Japan], June 1, 2001, Old Military and Civil Records, National Archives and Records Administration. Ms. Livingston confirms that Lendeveg's sentence was "rescinded by the U.S. Attorney General's office." 